\title{
COMPARATIVE STUDY ON THE USE OF DIFFERENT SOLVENTS AND THEIR EFFECT ON THE STABILITY OF PPR ATTENUATED VACCINE
}

\author{
Hussein, G. M. and Daoud, A. M. \\ Velerinary Serum and Vaccine Research Instlute. Aubasla. Calro
}

\begin{abstract}
Peste des pelils ruminants (PPR) virus as one of Morbillivirus (Paramyxoviridae) is a heal labile virus. In Egypl. as a hol-counlry in general we are urgently in need 10 find out a sulable solvent that may be act as heat loterant. In this work, we tried lo select the best solvent which provid a longer stabllly of reconstituled PPR vaccine six new solvents wre sludted in a comparative wllh the tradilional control solvent fohysiologi. cal saline solution). These solvent solutions included physlological saline solution. I M magnesum sulphate solulion ( $\mathrm{MgSO}_{4}$ ). 2.5\% lactalbunin hydrolysate solution. a mixture of laclabumin hydrolysate $2.5 \%$ and sucrose $5 \%$ solution. $5 \%$ sucrose solution, a mixture of I M magnesium sulphate and saline solution and dimethyl sulfoxide $2.5 \%$ solution. By using these solvents solutions. the reconslituting PPR vaccine was kept on ice and at $37^{\circ} \mathrm{C}$. Hiration of the uirus infectivily on Vero cells was carried out at 0.1 and 2 hours post reconstitution. It was reveuled that the besi solvent solulton was the mixture of $2.5 \%$ laclalbumin hydrolysate and $5 \%$ sucrose that could keep the loss in the origual virus litre at the most minimum.
\end{abstract}

\section{INTRODUCTION}

Pesle des petits ruminants (PPR) virus is a highly contaglous Morbillivirus iniecting sheep. goats and other small ruminants (OrE, 1998).

PPR is a weak virus and could be affected by surrounding temperalure. Appel et al. (1981) noted that inactivation of PPRV at varlous temperalures varles greatly depending on (he sul). strate, viral concentration and the virus had liall lives of $2-3.4$ minutes at $56^{\circ} \mathrm{C} .10$ minures al $45^{\circ} \mathrm{C}$. $1-3$ hours at $37^{\circ} \mathrm{C}$ and 9.1 ) days at $4^{\circ} \mathrm{C}$. They added that the addition of sodium or nagnesium sulphate dclayed heal inactivation of the virus.

It is well known that vaccination ts the best neans for animal protection against infectious diseases. 
Live attenuated virus vaccines were developed to protect sheep and goats agairist PPR disease (Couacy et al., 1995; Khodelr and Mouaz, 1998 and afaf, 1998).

The maln goal of the present work was targeted to the potentlation of valldity-span ol tIme for the reconstltuted live PPR vaccine at ambient temperatures, through determinalion of a most suitable protective solvent to be used for reconststution of the vaccine.

\section{MATERLAL AND METHODS}

\section{Vacclne solvent solutions:}

Six different solvent soludions were experimented to reconstitute the PPRV vaccine. They were: (1) Physiological saline solution. (2) $1 \mathrm{M}$ magneslum sulphate solution. (3) 2.5\% lactalbumin hydrolysate solution. (4) a mixture of $2.5 \%$ laclalbumin hydrolysate and 5\% sucrose solu. tlon, (5) 5\% sucrose solution. (6) a mixture ol $1 \mathrm{M}$ magneslum sulphate and physlologlcal saline solution (7) $2.5 \%$ dimethyl sulfoxdde solution (DMSO).

These solutions were prepared and stenllzed by nltration and were kept cold at $4^{\circ} \mathrm{C}$ tIll time or use.

\section{PPRV vaccine:}

The locally produced PPRV llve vaccine was used to lest its stabllity after being reconsticuled in seven different solvents. Thls vacclne was dertved from a local PPRV Isolate designaled as Egypl-87 (House, 1987). Requlred number of vaccine vials were randomly cullccted from a rou. tinely produced batch.

\section{PPRV titration:}

Infectivity Utrations were periormed on vero cell (Yasumura and Kowatika. 1963) (or the PPRV vaccine batch as well as for each of the seven reconstltuted vaccine samples dissolved in seven diflerent solvent solutions.

The geometric mean infectuity citre was expressed in log 10 TCiD 50 per ml as calculated by

\section{Reed and Muench Formula}

\section{4. stabllty testiong of the Hve PPRV dissolved in seven different solvents as kept on ice:}

Thls experiment was carried out through reconstituting the PPR vaccine vial content per each of the seven aforementioned dlluents kept on lce for the subsequent 2 hours. Representative samples per each of them were titrated for PPRV infectivity on vero cells at 0.1 and 2 hours post 
reconsitution. The gcometric mean virus tutre of three samples per solvent was takett and eacls virus titration result was calculated by Reed and Muench (1938).

5. Stabllity testing of the live PPR vaccine dissolved in geven different solvents as kept at $37^{\circ} \mathrm{C}$ :

This lest was donc as mentioned abuve except that the reconstltuled vinls in different cilluents were held at $37^{\circ} \mathrm{C}$ for 2 hours.

\section{RESULTS}

1. Stabulty testing of the live PPR vaccinc recaustituted in seven different solvents kept on ice:

Results of such lesting are given in Lable (1) and fig. (1).

2. Stablity testing of the LVe PPR qaccine reconstituted in seven different solvents held at $37^{\circ} \mathrm{C}$ :

Results of these experiments arc shown in table (2) and ng. (2).

\section{DISCUSSION}

The maln inconventence of most of the Marblliwisus live vaccines, is their heat instablity after being rcconsticuted PPRV live vaccine. being manufacturcd in Egypl for exportation purposes. Is nol an exception. Hence. It was of Interest to find oul a sultable solveril solution that might be used as a heal colerant reconstutuent for this vaccilne. In Ihis aspect. seven different solutions were (rled being experlmenled first through kceplng the dissolved vaccine on ice (Table 1), thus. simulating the field practical recornmended condicions and secondly through holding 11 at $37^{\circ} \mathrm{C}$ (Table 2) which might be the case of unavalabillty of ice in some field occasions. Among these solvents the mixturc of $2.5 \%$ lactalbumin $/ 5 \%$ sucrose was found 10 be an elficaclous solvent solution. In that only $0.5 \log _{10}$ TCID 50 was lost after a period of 2 hours on ice (Table I).

Moreover, only one log loss was fourid after a penod of 2 hours at $37^{\circ} \mathrm{C}$. Thus, such a reconstliuting solution proved to be an adequate diluent that could support a reasonable HPRV ure over a perlod of 2 hours exposure elcher on ice or at $37^{\circ} \mathrm{C}$ (Tables 1,2 ).

On revlewing the currelated literalure. It was found that the object of prolongation of the validicy span of a reconstltuled Morbillivirus vaccine was largeted by several authors (Languat et si.. 1985: Plowright, 1972: Mouaz et al, 1998 and Abeer, 1993). It is roleworthy lo menuon that the live PPRV vaccine ysal manufaclured to contaln $5 \log _{10}$ TCID 50 per $\mathrm{ml}$ of the lyoplisized 
product is sumclent to vaccinate 100 heads of sheep or goats. However. it is delivered arbitranly for only 50 heads. So. each anlmal will receive $\left(2 \times 10^{3}\right) \mathrm{TClD}_{50}$ although only $10^{2.5} \mathrm{TClD}_{50}$ is required for each animal (ONE, 2004).

Thus. in vlew of such a requirement. a PPR virus titre of $4.5 \log _{10} T_{C I D} D_{50}$ post exposurc for 2 hours on ice is quite satisfactory to vaccinate 50 animals.

On the other hand. even though a PPR virus llure of $4 \log _{10}$ TCSD50 wlll salisly the need to vaccinate 50 animals which is the case with holding the dissolved vaccine at $37^{\circ} \mathrm{C}$. The inherent reason which lles behind the efficacy of the laclabbumin sucrose inlxture might be altributable to the blochemical nature of both sugars and proteins. Thus. working lir a combination 10 protect virus particles against the influence of temperaturc. It could be concluded that results obtained In the present study would be a good contribution to the avallable knowledge in this concern. 
Table (I): Results of stability lesing of the live PPR vaccinc reconslituled in scven diflereni solvents kejut on ice.

\begin{tabular}{|c|c|c|c|c|}
\hline \multirow{2}{*}{ No } & \multirow{2}{*}{ Solvent } & \multicolumn{3}{|c|}{ Hours post reconstitution } \\
\hline & & $\overline{0}$ & 1 & 2 \\
\hline 1 & Physiological saline solution & $5.0 *$ & 4.5 & 4.0 \\
\hline 2 & $\mathrm{M}$ mag sulf solution & 5.0 & 4.0 & 4.0 \\
\hline 3 & $\begin{array}{c}2.5 \% \text { lactalbumin hydrolysste } \\
\text { solution }\end{array}$ & 5.0 & 4.0 & 3.5 \\
\hline 4 & $\begin{array}{c}\text { A nixture of } 2.5 \% \text { lact. alb., } \\
5 \% \text { sucrose solution }\end{array}$ & 5.0 & 4.5 & 4.5 \\
\hline 5 & $5 \%$ sucrose solution & 5.0 & 3.5 & 2.5 \\
\hline 6 & $\begin{array}{l}\text { A mixture of I M mag. sulf } \\
\text { solu. And saline solution }\end{array}$ & 5.0 & 3.5 & $3.5^{\circ}$ \\
\hline 7 & $\begin{array}{c}25 \% \text { dimethyl sulfoxid } \\
\text { solution (DMSO) }\end{array}$ & 5.0 & 4,0 & 30 \\
\hline
\end{tabular}

PPRV titres expressed as log 10 TCID

Table (2): Results of stability icsling of the live PPR vaccine reconstiluted in seven differen solvents held at $37 \mathrm{C} \mathrm{C}$.

\begin{tabular}{|c|c|c|c|c|}
\hline \multirow{2}{*}{ No. } & \multirow{2}{*}{ Solvent } & \multicolumn{3}{|c|}{ Hours posi reconslitution } \\
\hline & & 0 & 1 & 2 \\
\hline ! & Physiological saline solution & $5.0^{*}$ & 4.0 & 3.5 \\
\hline 2 & I $\mathrm{M}$ mag. sulf. solution & 5.0 & 3.0 & 3.0 \\
\hline 3 & $\begin{array}{l}2.5 \% \text { lactalbumin hydrolysate } \\
\text { solution }\end{array}$ & 5.0 & 4.0 & 30 \\
\hline 4 & $\begin{array}{c}\text { A mixture of } 2.5 \% \text { lact. alb. } \\
5 \% \text { sucrese soiution }\end{array}$ & 5.0 & 4.0 & 4.0 \\
\hline 5 & $5 \%$ sucrose solution & 5.0 & 3.0 & 2.0 \\
\hline 6 & $\begin{array}{l}\text { A mixture of I M mag. sulf. } \\
\text { solu. And saline solution }\end{array}$ & 5.0 & 3.0 & 3.0 \\
\hline 7 & $\begin{array}{l}2.5 \% \text { dimethyl sulfoxid } \\
\text { solution (DMSO) }\end{array}$ & 5.0 & 3.0 & 2.5 \\
\hline
\end{tabular}

TPI'RV titres expressed as log lo TCID $_{4}$ per $\mathrm{ml}$ 

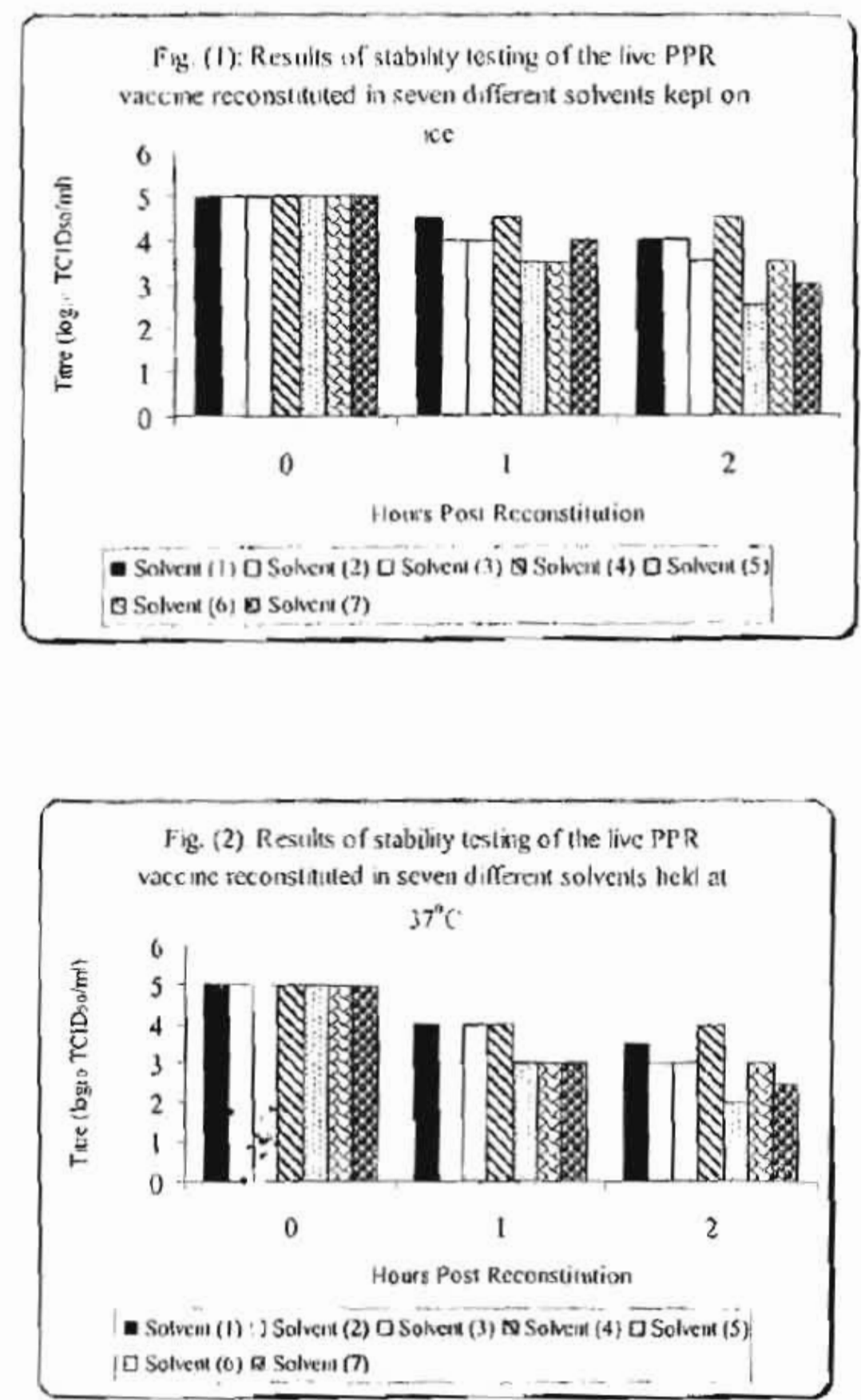


\section{REFERENCES}

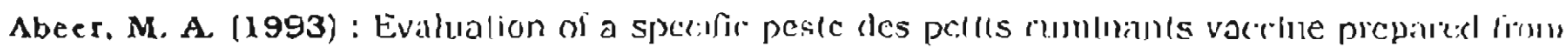
lerall vilus strain. M.V.Sc. Degrec. Virolngy. Cairo Uriv.

Anf. A. A. (1998) : Some studies on thermoslable peste des petits luminants (PPR) vitus vas. cinc. I'h.D. Vel. Sel. Thesis. Inlectious Discases. Fac. Vel. Med. Cairo Univ.

Appel, M. J. G.; Gibbs, E. P. J.: Martin, S. J.; Meulen, T. V.; Rlma, B. K.: Stepherson, J, R. and Taylor, W. P. (1981): Morbilluirus discases of auinials nd man comparalive diak. nosis si viral dlseisc. Vol. N. Chap. 6: 235-297. Acadoult: Press lculled by lidourinl and Clirisune Krustak).

Couacy, H. E.; Bidjeh, K.; Angba, A. Domenech. J. and Diallo. A. (I 995) : l'alection ) igoals agalnst rinderpest by valccination with attenuated peste des pelus ruminanis virus. Res. Vel. Scl., 59 (2): $106-109$

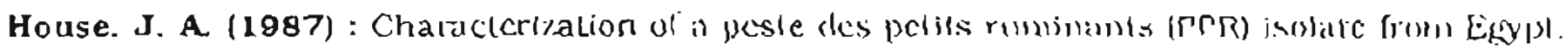
(Mcinurandum for the report\}. Plum island AnInal Disense Centre, N.Y. USA.

Khodelr, M. H. and Mouaz, M. A. (1998) : Pieparatien of a specilir peple varcunc. 5ll Sri. Comks. Fus: Vel. Med.. Cairo Univ., 709-717.

Languet, B.; Precausta, P.; Mackowiak, M.: Dubourget, P.; Reynaud, G. and Duret, C. (1985) : lirce\%e-dried against rinderpest stability and actlvity sludy. Comparative inmolinulokv. Microblulogy and Infectious Diseases, 8 (3/4): 285-295.

Mouaz, M. A. Gehan, KM.; Khalrat, A. E.; Alda, I. E. and Khodeir, M. A. (1998) : Lvilluallon

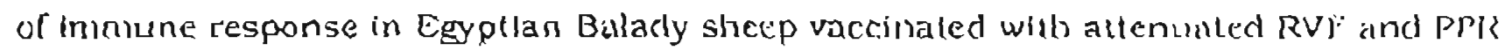
vaccincs. Asslut Vcl. Med. J., 38 (76): Jan 1998.

OIE (1998) : OIE (nternational Committee report of the 66lh geneial sesston. Paris, 25)-29 Mil,'. 1998. P.S. Animal Disease Status Woriclwicle in 1997.

Ore (2004): Manual ol Dlagnoslic Tests aud Vacrines lise Terlestlial Animals. 5uh celulion).

Plowrigbt. W. (1972): The production and use of rinderpest cell culture vaccine in developing countrics. World Autinal Revicw, 1: 14- 28.

Recd, L. J. and Muench. H. (1938) : A shmple nelhod of esllinating lity percent end points. Am J. Hyg.. 27: 443 .

Yasumura, Y. and Kawatika. Y. (1963) : Studics on 5V40 vîus in lissue culture. Nihon IRlırsho. 21: $1201-1215$ 
اللانحص العربم

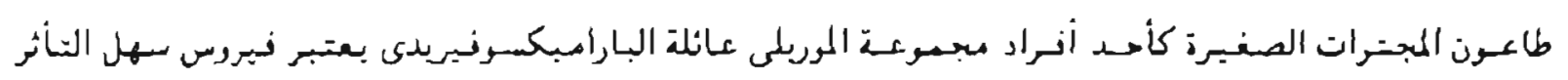

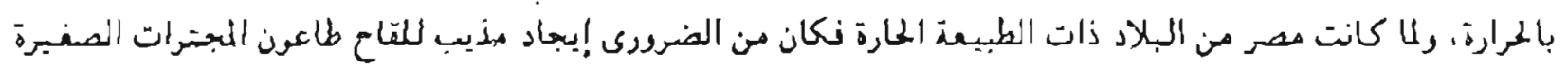

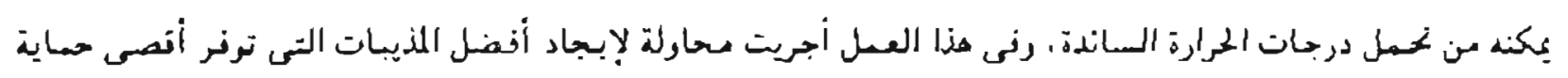

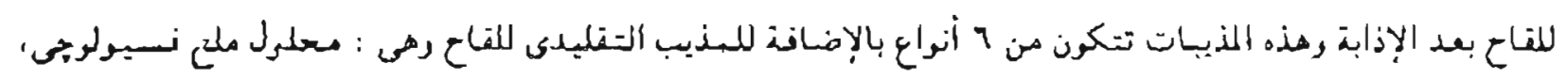

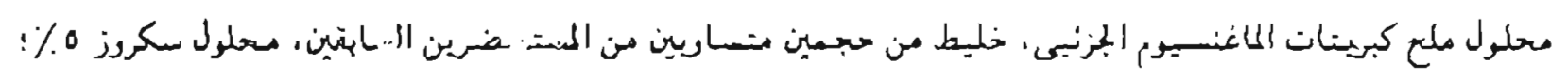

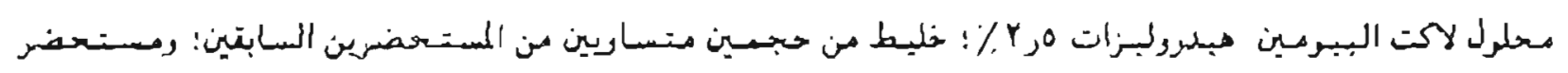

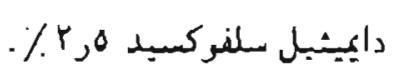

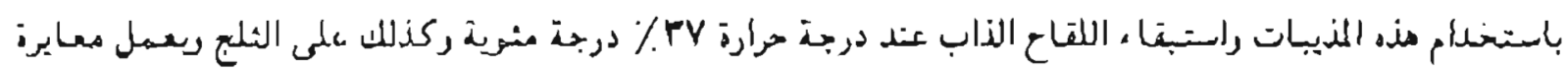
لكل منهمر وعلى نتراث منتلفة (بعد الإذابة مباشرة وبعد ساعة ثم بمد ساعتين) .

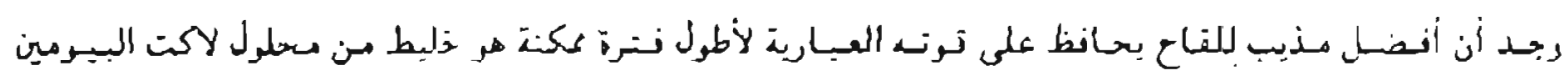

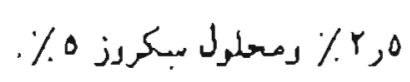

